\title{
Erratum to: Atypical chronic myeloid leukemia with concomitant CSF3R T618I and SETBP1 mutations unresponsive to the JAK inhibitor ruxolitinib
}

\author{
Emanuele Ammatuna ${ }^{1} \cdot$ Matthias Eefting $^{1} \cdot$ Kirsten van Lom ${ }^{1}$. \\ François G. Kavelaars ${ }^{1}$ • Peter J. M. Valk ${ }^{1}$. Ivo P. Touw ${ }^{1}$
}

Published online: 31 March 2015

(C) Springer-Verlag Berlin Heidelberg 2015

Erratum to: Annals of Hematology

DOI 10.1007/s00277-014-2272-0

The original version of this article contained a mistake in the author name. The author François F. Kavelaars should be presented as François G. Kavelaars.

The online version of the original article can be found at http://dx.doi.org/ $10.1007 / \mathrm{s} 00277-014-2272-0$.

\section{Emanuele Ammatuna}

ammatuna@gmail.com

1 Department of Hematology, Erasmus University Medical Center, Cancer Institute Daniel den Hoed, Groene Hilledijk 301,

3075 Rotterdam, The Netherlands 